\title{
Heroes, Fans and the Nation: Exploring Football in Contemporary Fiction
}

\author{
Alexis Tadié \\ University of Paris-Sorbonne. Institut Universitaire de France.
}

\begin{abstract}
This paper argues that the football trope in literary fiction enables the writer to explore the workings of modernity. In doing so, writers define a place for the reader, which is parallel to the spectator's at a football match. If football may be seen as a form central to our thinking about modernity, the decentering of the analysis brings to light different, splintered, modernities. This study concentrates on English football, as well as on the place of Irish soccer in contemporary Irish culture, or on the writings of the Hungarian novelist Péter Esterházy, who places football at the centre of his writings. This paper concentrates on heroism in football, before turning to an analysis of audiences. Finally, the paper focuses on the relationship between football and the nation in literature.
\end{abstract}

Keywords: football, soccer, reading, Brian Glanville, Dermot Bolger, Péter Esterházy, David Peace, John King.

In Harold Pinter's The Dumb Waiter (1960), two characters, Ben and Gus, find themselves in Birmingham and start discussing the possibility of watching some football. Gus is excited at the prospect ('We could go and watch the Villa') while Ben dampens his enthusiasm ('They're playing away'). They discuss having watched a game once, between Aston Villa and Tottenham Hotspur:

GUS : I've always been an ardent football fan. Here, what about coming to see the Spurs tomorrow?

BEN (Tonelessly) : They're playing away.

GUS : Who are?

BEN : The Spurs.

GUS : Then they might be playing here.

BEN : Don't be silly.

GUS : If they're playing away they might be playing here. They might be playing the Villa. BEN (Tonelessly) : But the Villa are playing away.

(Pause. An envelope slides under the door, right. GUS sees it. He stands, looking at it.)

GUS : Ben.

BEN : Away. They are all playing away. ${ }^{\mathrm{i}}$

*email : alexis.tadie@paris-sorbonne.fr 
This dialogue between the two characters about football is not the only sporting reference in Pinter's work (cricket in particularii ${ }^{\mathrm{ii}}$ ); the focus of the exchange is here as much on football as on the endlessly deferred desire to watch it. Discourse comes to replace the game, Ben dismisses Gus's endeavours and has all the teams 'playing away'. In this perhaps, we may find some features of conversations about football: they take place in the absence of any game, they re-enact the game (Gus and Ben discuss at one point, as we all do, a dubious penalty decision), they stand perhaps for the game. This exchange between the two characters is emblematic of literature about football, preferring to concentrate on the fans and their attitudes ('I've always been an ardent football fan'), on memories of the game, on the spectators' perceptions rather than on the game itself.

Not all literature is about spectators, of course. The literature about football is a distinct field within sporting literature. It covers several genres, ranging from popular fiction for children to complex fictional constructions, such as David Peace's The Damned United (2006). Roy of the Rovers was for instance a comic strip which was published in the magazine Tiger, before becoming a weekly publication which focused on the football player, Roy Race, who played for Melchester Rovers. His adventures and feats and performances were the focus of young boys' expectation and admiration for many generations of English boys. It fostered a love for football, and Roy of the Rovers has become a mythical character. Other familiar characters include Hot Shot Hamish, who played for Scottish League club Princes Park. The heroics of such characters are to be found in a number of publications for young readers. They start with the books by Sidney Horler, of which Goal! A Romance of the English Cup Ties ${ }^{\mathrm{iii}}$ is probably the most famous. And their lineage can be traced back to the public school novel, in the wake of Tom Brown's School Days ${ }^{\text {iv }}$. Such literary activity for children is of course extremely developed in England. It connects with the development of sports in schools in England in the nineteenth century, analysed by J.A. Mangan in a number of books. It exists perhaps less prominently in other national traditions. ${ }^{v}$

Popular literature also includes a number of football fans' accounts of campaigns, such as Peter Davies's All Played Out: The Full Story of Italia '90, which is a report 
on England's great but ultimately unsuccessful campaign. ${ }^{\mathrm{vi}}$ The genre of the footballer's autobiography has developed over the last fifty years. These autobiographies construct, according to Joyce Woodridge who has analysed them, "the dominant consensual ideal of masculinity", as well as they show "the emergence of alternative masculine constructions that are part of wider cultural shifts". vii The dominant model for such autobiographies is the exemplary life but this does not preclude the possibility of such texts taking the form of a confession, such as Jimmy Greaves's This One's on Me (1979), which does not shy away from an account of his alcoholism, or George Best's Where Do I Go from Here? (1981). ${ }^{\text {viii }}$ Over the last twenty years or so, the genre has developed through the emergence of a media system that favours individual heroes in a collective sport. Biographies of football players are also ubiquitous, and constitute a large proportion of the field of sporting literature. But there are important literary essays about sportsmen, which do not address the same literary, or indeed, marketing concerns. Ian Hamilton's essay about the enfant terrible Paul Gascoigne, aka Gazza, Gazza Agonistes, ${ }^{\text {ix }}$ was first published in the literary journal Granta in 1993. It is a fan's account of one of the great heroes of British football which points unambiguously to the literary and mythical dimension of the character as well as of the text (the nickname 'Gazza' rather than Paul Gascoigne, the reference to Milton). The book charts chronologically the ups and downs of the career of a genius and a bad boy, of a hero and a victim, and it embodies the literary potential of Gascoigne's career, displaying the peculiar relationship that literature and sport may entertain, addressing as much the myth of 'Gazza' as Paul Gascoigne, the player. One could add to this brief survey of the genres, historical essays, such as David Winner's Those Feet: A Sensual History of English Football. ${ }^{\mathrm{x}}$

Fiction plays a part in the perception of the sport. One encounters in the Englishspeaking world the greater number of texts that either focus solely on football, such as Brian Glanville's novels, or that display an awareness for the game, such as the excerpt from Harold Pinter quoted above. Although Glanville can be seen as a precursor of the genre, and perhaps the first novelist to have based a significant number of novels on football, the 1990s saw the emergence of a number of important literary texts, such as Nick Hornby's book about his life as an Arsenal supporter, Fever Pitch (1992), written in the days when the London team was synonymous with a tedious form of football. It explores an obsession and analyses the meanings of 
football, in a book which has proved to be a model for writings of, or about, fans. ${ }^{\mathrm{xi}}$ John King's trilogy The Football Factory, Headhunters and England Away, published between 1996 and 1998, is part of a series of novels such as Hooligan (1998) by Eddy Brimson, or Casual (1996) by Gavin Anderson which reflect on the fortunes of hooligans, but whose plots address both issues connected with football as well as with society as a whole. ${ }^{\text {xii }}$ Footballers themselves have been keen to indulge in literatury fiction, such as Derek Dougan, the Northern Irish footballer who published The Footballer (1974), Jimmy Greaves, who collaborated on a number of projects with Norman Giller, and Eric Cantona, who has now become a successful actor, was also famous for being a poet.

This paper argues that the football trope in literary fiction enables the writer to explore the workings of modernity. In doing so, writers define a place for the reader, which is parallel to the spectator's at a football match. Through a meditation on the aesthetics of the game and on the complex nature of readership/spectatorship, football fiction prompts a reflection on the nature of modernity, nationalism, class and gender. Further, although a large body of writing about football has emerged in England, the country that invented association football can by no means be seen as the sole source of literature on the subject. This is why the present paper extends beyond English representations of football in order to address larger concerns. If football may be seen as a form central to our thinking about modernity, the decentering of the analysis brings to light different, splintered, modernities. Alongside works of English fiction, this study will therefore concentrate on Dermot Bolger's plays about football and the place of Irish soccer in contemporary Irish culture, as well as on the writings of the Hungarian novelist Péter Esterházy, himself a footballer of some talent. This paper first concentrates on heroism in football, and in particular on the fictional focus upon star players. The paper then turns to audiences - the football audience, the reading public —, and analyses the bonds between supporters and their teams. Finally, the paper turns to the relationship between football and the nation in literature, in order to bring to light varying modes of defining and understanding modernity through football.

1. The heroes of football 
The various literary works about football address two broad concerns. The first type concentrates on heroes, sometimes on fallen heroes, and investigates the lone ranger in what is, after all, best described as a team sport - it fulfills one of the ancient functions of literature about sport, the celebration of heroes. xiii The second type, exemplified most famously by Nick Hornby's Fever Pitch, lays more emphasis on spectators and on the attitudes of spectators than on the game itself.

Fictional portraits of sportsmen redefine the celebrated genre of the biography, or the autobiography, of famous footballers - albeit often ghost-written. These portraits may be visual, such as Ken Loach's Looking for Eric (2009), ${ }^{\text {xiv }}$ which is not so much a biography of the great French footballer Eric Cantona, but a fictional evocation of the fascination the player exerted over the public. It is a portrait of Cantona, whose mythical interventions, both on and off the field, are revisited through the eyes of a fan, the central character of the film, Eric Bishop, at the same time as it is a film about the power that such stars can exert over the fans. In having Cantona play his own role in a fiction, and reflect upon the glorious and less glorious moments of his career, the film straddles the border between fiction and non-fiction, and suggests that fiction is sometimes best equipped to investigate the (real) nature of the game. ${ }^{\mathrm{xv}}$ Like cinema, the literature of football approaches "historical" footballers in ways that transcend the subjectivity of writing and fashions them into complex figures of discourse. This potential can be exemplified by Ian Hamilton's (non-fictional) account of Paul Gascoigne. On the last page, reflecting on Gazza's exclusion from the 98 World Cup by the England coach, Hamilton writes: “Glenn Hoddle's icy pragmatism has thwarted our hunger for, shall we say, the accidents of narrative. His was a prose decision and our disappointment, so we like to think, partakes of the poetic. Simply on aesthetic grounds, Gascoigne's exclusion from the 1998 World Cup was a calamity." "xvi This is more than a metaphor. Hamilton suggests that literature enables us to make sense of football in terms of conflicting literary modes (prose or poetry). The aesthetic dimension of football lies not only in its visual dimension, but also in our understanding of the game.

This can further be apprehended in fiction. Brian Glanville's The Dying of the Light (1976) constructs and explores the lonely, romantic figure of a (fallen) professional 
football player. Glanville, a leading football commentator, has published a number of novels, which focus on sports, ${ }^{\mathrm{xvii}}$ and mainly on football. ${ }^{\mathrm{xviii}}$ In The Rise of Gerry Logan (1963) for instance, he concentrated on a central character, Gerry, who was a Scottish inside-forward based on Danny Blanchflower. In The Dying of the Light, Glanville examines the plight of Len Rawlings, once the revered goalkeeper of the England team (and of various clubs), now jobless, a dangling man hunted by his past as much as by the law. Like in The Rise of Gerry Logan, the novel alternates chapters narrated by his son, by his daughter, and by Len himself. The contrasting viewpoints on the character enable not only an investigation of his downfall but also a perspective on the world of football and its changes, through the fortunes of the main character. The glory and the ruthlessness, the joys and sorrows, the financial priorities over the sporting achievements, the support and the treasons all appear in contrasting lights thanks to this narrative construction. Glanville's Len appears as a victim, a victim of the "system" perhaps, but also a victim of the glory and the splendour that sport in general, that football in particular generates. ${ }^{\text {ix }}$ Beyond the investigation of the inner workings of a great sportsman, which is enabled by the choice of a distinct fictional strategy, the novel offers a perceptive analysis of the changing cultures of English football. Glanville was notoriously opposed to the creation of the Premier League, and his description of the world of football, some years before it was formed, shows a coherent, profound vision of the world of football. He is quick to understand the power of television: 'he'd 'seen it on the television', the story of our whole society, which found nothing real until it had been seen on television." ${ }^{\mathrm{xx}} \mathrm{He}$ is aware of what Len defines as a lack of gratitude, but which the reader understands to be about the structure of football, about an individual's contribution to the sport, about the fundamental transience of the game: “And talking to him now made me angry, not with him, he was all right, but with them, all the people that had pushed me out and kept me out, out of football, out of my life. What right had they to do that, any of them? How many of them had done as much for the game as me? It was still living on what I'd done, on what I'd been." ${ }^{\text {xxi }}$ The literary text allows for a perception of historical transformations, an understanding of the ways in which a central social and political phenomenon such as sport is appropriated and transformed.

The exploration of the workings of the actors of football through fiction is carried further in David Peace's The Damned United, a book that gained a certain amount of 
success, both through its publication and through the disagreements that surrounded the film adaptation of the novel. ${ }^{\text {xii }}$ Sometimes described as "factional", a term that refers to the use of real characters in fiction, it is the fictional account of Brian Clough's forty days as manager of Leeds United, in 1974, after they had won the league - and indeed the first document that opens the book is the final league table of 1974. It is subtitled "An English Fairy Story", and described by the author as a novel which is "another fiction, based on another fact". Fiction enables Peace to portray events in a deliberately subjective way, never pretending to tell the whole truth about them. This book can first be understood both in terms of Peace's works, which address the context of the Thatcher and post-Thatcher years in England. It investigates, in ways that other novels about football do, not only the nature of the game, and of the manager, but the political context of the Thatcher years. In his earlier $G B$ 84, Peace had focused directly on the 1984 miners' strike and on the political struggles of the period; in The Damned United, Clough, caught between his own personal achivements and the collective fate of the team, prefigures the contradictions of the Thatcher years, and the book indeed ends with a reminder that Margaret Thatcher became prime minister the year that Clough won the European Cup with Notthingham Forest. The novel can also be articulated to other fictions about sport, such as Running (2008) by Jean Echenoz, which is a similarly constructed fictional biography of the great runner Zatopek. ${ }^{x x i i i}$ Both novels share this ability to understand the private worlds of sportsmen through the modes of literature, but whereas Echenoz's novel takes the form of a third person narrative which deals with the character from the outside and yet tries to penetrate to the core of the runner's sensibility, Peace's novel about Clough lets the manager speak.

The Biblical duration of Clough's stint at Leeds (just over 40 days) shapes the novel into forty chapters that are like a diary, from day one to day forty. The chapters themselves alternate narration in the first person, when Clough recounts events, and narration in the second person, a form of inner monologue where Clough addresses himself, and remembers events beyond this forty-day period. This enables Peace to retrace Clough's career, to contrast his time at Derby County and his time at Leeds; it enables him to dramatise the character through the first-person and second-person narratives, through the construction of a voice. One of the first events to be recounted is indeed the injury that Clough sustained as a player and which put an end to his 
career: "You stop crawling. You turn over. Your mouth is open. Your eyes wide. You see the face of the physio, Johnny Watters, a worried moon in a frightening sky. There is blood running down your cheek, with the sweat and with the tears, your right knee hurting, hurting, hurting, and you are biting, biting, biting the inside of your mouth to stifle the screams, to fight the fear-". xxiv The way Clough relives past events through narration in the present tense and through the short, brutal enunciation of the pain, determines the tone of these inner thoughts. The rivalry with Don Revie, whose towering presence over Leeds United, which he managed for thirteen years, is the thorn in Clough's side, also defines the novel: "They are not my team. Not mine. Not this team, and they never will be. They are his team. His Leeds. His dirty fucking Leeds, and they always will be. Not my team. Never. Not mine. Never. Not mine. Never. Not this team. Never-". ${ }^{x v}$ Fiction enables Peace to construct a voice, an inner voice which resonates in the reader's ears. It is that voice which determines our understanding of the world of football.

The novel is framed by a quotation from the book of Jeremiah which anticipates the plight of Brian Clough in his forty days at Leeds, and builds him into an almost Biblical character, as well as by an argument, split into two parts at either end of the book, which places the narrative under the sign of literary and political references. William Wordsworth's sonnet about John Milton ("Milton! Thou shouldst be living at this hour") is quoted and echoed through the argument, introducing William Blake and George Orwell as other literary protectors whose absence is sharply felt in the days of Thatcherism. Antonio Gramsci is also present in this text as if to underline that we have reached a moment of crisis: "The old is dying and the new cannot be born". And the continuation of the argument at the end of the book confirms that the times are bleak. While the election victory of Margaret Thatcher in 1979 provides a landmark for a time beyond the narrative, the last words of the novel sound a note of despair: "No Milton. No Blake. No Orwell_-,xxvi The need for forceful literary and political voices is reasserted at the same time as it is denied. The heroes of yore are gone.

Glanville and Peace, like Hamilton in a non-fictional context, focus on the great heroes of football, on the fallen heroes; they all investigate the frailty of football, the solitude of the player or the manager. Whereas football is a collective sport, they draw 
attention to the complex heroism of the individuals, to the ambiguous cultures of masculinity, and to the ways in which heroes can fall victim to the game, beyond the football pitch. Their solitude resonates in a political context, where the individual is cut off from the community, where hubris comes to replace solidarity. The celebration of heroes, one of the great topics of sport writing, here takes a darker turn, one that literature is perhaps best equipped to explore.

\section{The audience of football}

When they focus on heroes, these texts deliberately shun a description of actual games, opting to explore the social and cultural dimensions of the sport, rather than the unfolding drama on the pitch. And even when they focus on individual characters, they may well do this from the point of view of the fan, as exemplified by Hamilton's book. Indeed, it is a fan's account, not only in that it presents the partial view of the Spurs supporter, which it does, but because it makes sense of the world of football, and of Gazza's place in this world, from the point of view of the supporter: "to appreciate Hoddle's vision and finesse you need to have rare powers of discrimination. To fret for hours about whether or not he will do the business against Kuwait you need to be short of something else to think about. I also like to pretend that such a fan must be equipped with unusual qualities of loyalty, persistence and fortitude in the face of accumulating set-backs." ${ }^{\text {xxvii }}$ This is of course, rather famously, the perspective adopted by Nick Hornby in Fever Pitch. This book is not so much about football, but about a passion for football, or rather, about how a passion for football constructs a worldview. The world makes sense, the structure of memory makes sense only in the context of the progress of Arsenal. Events are only charted in relation to specific football matches so that the dividing line between fiction and nonfiction becomes blurred - Hornby's text may be considered as a fictional construction based on the actual diary of a fan. This generates a form of identification between the reader and the fan-as-writer, which is peculiar to football. Indeed, where literary representations of cricket for instance are more attuned to the strategies, and excitement, and suspense, and values of the game, football literature seems to concentrate on the workings of the fan, on his passion and anxieties and triumphs. ${ }^{\text {xxviii }}$ 
This perspective is further explored in John King's trilogy The Football Factory, Headhunters and England Away. Set around games of football, around Chelsea FC as well as the England team on the occasion of a Germany-England game, it investigates the culture that surrounds football matches, specifically, the cultures of fandom and hard masculinity in their most violent incarnations. ${ }^{\text {xxix }}$ It portrays a number of Chelsea supporters, white working-class, racist, disenfranchised, but not economic outcasts as such - they have jobs, earn enough money to live ("I work hard and keep my life in order" $\left.{ }^{\mathrm{xxx}}\right)$, and spend their weeks looking forward to the action of the Saturday. The narrator describes their predicament, the sense of being on the margins while defending their status with pride: "We're lower than niggers because there's no politician going to stand up for the rights of mainly white hooligans like us. And we don't want their help. We stand on our own feet."xxxi They have no politics ("a load of shit basically and you'll find little of it around here"xxxii); they only retain a tribal sense of the world as the only way to survive. Football defines solidarity and loyalty to a cause. This is something that had of course been previously described by J.B. Priestley in an often quoted passage of The Good Companions (1929) which insists likewise on the solidarity, oblivion and aesthetic that football affords: "here you were cheering together, thumping one another on the shoulders, swopping judgements like lords of the earth, having pushed your way through a turnstile into another and altogether more splendid kind of life, hurtling with Conflict and yet passionate and beautiful in its Art."xxxiii Most of all they escape all categories: "there's no label. We're something the rich cunts hate and slumming socialists can't accept. We're happy with life and there's no need for social workers."xxxiv

Unlike Hornby's narrative, these novels deal very little with football as such — one rarely gets an account of a game, or a look into the action on the pitch. Occasionally, the joy at a victory (thrashing West Ham 3-0, beating Villa away) brings a description of a state of mind: "the ball hits the net and we're jumping up and down going mental ... It's a good game of football and when the ref blows the whistle at the end we leave happy." ${ }^{\prime x x v}$ The narrator describes the atmosphere inside, the chants of supporters, the individual nature of stadiums that define the great football teams: "Old Trafford's a smart ground and when they write about Man U being a great club you know deep down they're right. Going to places like Old Trafford and Anfield gives you an extra kick. Football's all about atmosphere and if the grounds were empty and there was no 
noise, there'd be no point turning up."xxxvi But above all there is the peculiar feel of Stamford Bridge once the spectators have left: "The glow of floodlights had vanished, brilliant illumination replaced by deep shadow. Stamford Bridge stood out aginst the rolling clouds, light from a near-full moon catching the angles of the towering main stand." "xxxvii The poetry of the urban landscape, of the football stadium acts in sharp contrast to the violence that is unleashed around the games. There are a number of such moments when the world outside is suddenly peaceful and beautiful, and different from the reminders of urban violence. Having described the beauty of nature, the narrator spots a man, "a tattooed Hayes cunt turning back towards the coach. He throws his empty bottle into a bush. There's the smash of glass and a couple of distant cows turn their heads and they're probably thinking the bloke's a right wanker doing that in such a beautiful bit of countryside."xxxviii

The matches are against the police, and between supporters: "We're on the edge the whole time because West Ham's no joyride. Not like having a go at Arsenal or Tottenham." "xxxix The diaries of a hooligan which The Football Factory, in particular, construct, are a powerful means of forcing the reader to perceive this particular subculture, of making it visible. They record the changing attitudes in the grounds, the differing attitudes in the better policed grounds, the activity in the sixties compared to present day. Football is perhaps a pretext for the author who has devoted a number of books to the portrayal of these particular white working class groups ${ }^{\mathrm{xl}}$, it is even fortuitous for the hooligans: "Football is just a focus, a way of channelling things. If there was no football we'd find something else. Probably be a lot more indiscriminate as well. The aggression's got to get out some way..."xli And when in England Away, they go to Berlin for the big match, it's all about reclaiming their position, about reenacting the war, about not being "ordered about by Berlin." disenfranchised white working class, King does not merely analyse the nature of hooliganism, the springs of the violence, the bonding of the tribe; he throws light on the ways in which, in the Thatcher years, English culture generated its own contradictions, its dark areas and blind spots. There have of course been sociological or journalistic studies of hooliganism, but King's powerful fictional gesture lies in his giving voice to this subculture, in constructing the voice of the hooligans through fiction. Football in this sense is not so much the subject of the books but a central 
social phenomenon that reveals to the reader the complex and fractured nature of late twentieth-century modernity in England. ${ }^{\text {xliii }}$

Violence at football is also the subject of Laurent Mauvignier's novel, In the Crowd (2006). ${ }^{\text {xliv }}$ It focuses on a group of characters who gather at the Heysel Stadium in Brussels on 29 May 1985 for the European Cup final between Juventus and Liverpool, at which thirty-nine people died and about six hundred were injured. It is a complex novel, about wanting to see a football match, about the excitement generated by the approach of the game, about characters in the crowd. Mauvignier uses a shifting narrative viewpoint which focuses in turn on each of the characters and enables him to try and approach the senseless violence of that day, the disappearance of one of the characters, but also, three years later, the trial and the ways in which characters try to cope. It is only about football in the sense that the occasion for the novel, what makes the novel possible, is precisely this traumatic football match which is part of the common historical heritage of Europe. It is not about hooliganism either, but more about bonding and solitude in the face of tragedy. What matters, as in David Peace or John King's novels, is the voice of the different characters, their scars, the way they grope in the dark, the way they try and understand, the way they struggle to reach an ever-elusive meaning. Unlike King's trilogy, it is not about the hooligans, but rather about the senseless violence, about the haphazard ways in which it unfolds, about the frailty (physical, psychological) of characters. Football here is this central social cultural event which enables the exploration of the arbitrary violence which runs through our society. And the book may further be seen to be investigating more generally our reactions to senseless, anonymous violence, and the ways in which we deal with it, such as that unleashed on 11 September 2001.

In their investigation of the workings of football, a number of fictional texts choose to focus on the supporters and the public, rather than on the games themselves. In doing so, like Fever Pitch, they elucidate the obsessions associated with being a football fan. They can also reveal, like King's trilogy, the anxieties of disenfranchised individuals who find a common bond in the violence of football. They address the ways in which we cope with blind violence, at a football match and beyond. In doing so, they underline the centrality of football in our societies. 


\section{Football and the nation}

Whereas The Football Factory investigates the allegiances and the worldview of the club hooligan, the context of England Away enables King to transcend club allegiances ("We're all England"xlv), and to analyse the workings of nationalism. This nationalism is set against the bravery of other characters in the war, as if football enabled the author to concentrate on the workings of the modern world, on the concepts of nation and class, on the connections between the wars of the hooligans and the real wars fought fifty years before. The meaning of violence is summed up at the end of England Away, when Harry watches with pride the bands of hooligans marching past: "It was the feeling of power you could only get from everyone mobbing together. Sex gave you something, but the threat and use of violence was something else. It let you play God for a while, like you could do whatever the fuck you wanted and nothing could touch you and make you pay a price." ${ }^{\text {xlvi }}$ Football is of course notorious for fostering both club passions and allegiances, and for releasing the tensions of jingoism. Eric Hobsbawm has shown that the process originates between the two world wars, when international sport became an expression of national struggle. A football team can embody the nation and pass on the reality of it to the supporter, who, as Hobsbawm explains, "becomes a symbol of his nation himself."xlvii When literature turns to the relationship between football and the nation, the workings of sports jingoism may ultimately be redefined. It is thus important to look beyond England, to investigate the ways in which the trope of football brings to light the workings of nationalism. In turning to two authors who have used football in their fictions to investigate feelings of belonging and bonding to the nation, one may see conflicting modes of appropriating the nation and its (football) past.

The Irish writer, Dermot Bolger, has explored the place of Irish soccer in the relationship between the Irish and their country, in two monologues: In High Germany (1999) and The Parting Glass (2011). ${ }^{x l v i i}$ The first of these monologues looks back to Euro ' 88 when Eoin, the main character, first heard that his son was going to be born. The text takes the form of a speech addressed by Eoin to his elevenyear old son; he remembers the Euro, the fans and the atmosphere and the excitement generated by the Irish team which very nearly qualified for the semi-finals (Ireland 
were beaten by a late goal from the eventual winners, Holland). Above all, the text reflects on notions central to the definition of Irishness, such as memory, exile (most of the fans are migrant workers), home and family. Support for the national football team enables Bolger to investigate the changing definitions of the nation. Thinking back on the mid-seventies, when an increasing number of English-born players claimed Irish ancestry in order to play for the Irish team, and generated suspicion, Eoin notes: "That was back then, when I still believed in that sense of what being Irish was. When they did not fit into my vision of Ireland."xlix Because it is a sport which, at least for the fans, is based on memories and compilations of facts, the memories of football (such as the Liam Brady goal against France in an otherwise disappointing campaign to qualify for the 1978 World Cup) trigger off meditations on the feeling of separateness from the home country: "But it wasn't really football we were thinking about any more. It was something else. Something we had lost, that we had hardly even been aware we'd had. That dream of finally getting into some big finals and of coming home to Dublin with stories to tell people. There is no greater feeling than the feeling of going home, of having a home to go back to." Eoin reflects on the impossibility of going home, on the displacement of home for a people whose condition is that of emigration. Eoin's final acceptance of exile, of the fact that there is no going back, of the fact that he is staying in Germany, where his son will be born, goes hand in hand with the realisation that belonging to the nation can also take place abroad — the Irish football team provides that feeling of belonging: "The crowd joined in with me. Every one of them. From Dublin and Cork. From London and all over Europe. And suddenly I knew this was the only country I still owned. Those eleven men in green shirts, half of whom were born abroad."li

The sequel to In High Germany, The Parting Glass, was first performed on stage in 2010 and published the following year. It takes place on the night when Ireland were famously defeated single-handedly by France's Thierry Henry and failed to qualify for the finals of the World Cup. ${ }^{\text {lii }}$ Although several voices are heard, the play is a oneman show which allows Eoin, now fifty, to reflect on the past, on his childhood with an absent father who had to work in England to earn a living, ${ }^{\text {liii }}$ on his own emigration in the 1980s to try his luck elsewhere, on his friends whom he last saw at the end of the Holland game in 1988, and with whom he is reunited that night: Shane, and Mick, who died in the States and had arranged for his ashes to be sent to his friends. Eoin's 
son, Dieter, who is more German than Irish, accompanies them. But Eoin, we learn, has gone back to Ireland, perhaps for his mother who is ill, mainly for himself, to claim his inheritance in a country which has been strangely affected by globalisation: "Ireland is a jigsaw under construction. It is Polish shops and Romanian bodybuilders and African mothers outside schools. It is unexpected estates dropped from space. It is Sunday walks with Frieda on Howth Head to show her pubs I remember and find places I don't." "liv We learn that after the death of his wife, he has invested all his money in the new Irish economy, only to lose it, as Ireland goes under, and to find himself once again queueing for jobs. ${ }^{\text {lv }}$ His meditation takes the form of a long remembrance. We hear the echoes of would-be financial tycoons, we listen to the evocation of derelict landscapes of half-built estates, we perceive the repetition of patterns when his son Dieter emigrates to Canada. In this context, football affords solace, and above all a collective experience, which Bolger records: "We may be broke and scarred as a nation, but once the game starts we forget everything as we sing our hearts out for the lads. For ninety minutes I can even set aside the fact that my son is about to emigrate, because every primeval instinct from my boyhood is kicking in."lvi

Football models what happens to the country as a whole: when Henry has the grace to apologise for what happened, he stands in contrast to the bankers, developers and politicians who cheated the country and never apologised. Football enables Bolger to explore the lives of individual Irishmen, of emigrants who have gone back home, to investigate the massive robbery that was enacted upon the Irish people: "if Irish people were left with a sense of feeling cheated, then Thierry Henry was only a bit player in the collective sense that we have been massively robbed."lvii Football, finally, provides Bolger with the means to meditate on the relationship between individuals and the nation: "I let myself believe in the country that fucked up my father, that shipped off my uncles and aunts like cattle on the hoof." "lviii Literature enables writers to investigate the connections between individual perspective and national narrative, to turn received ideas on support and jingoism into complex webs of intertwined stories. Both King and Bolger give voice to the fans, give a voice to football supporters and reflect on their psyche as much as on the economic political conditions which they have to face. Fiction provides a broader outlook on football, one in which the game affords a worldview for the characters. 
The books of the Hungarian writer Péter Esterházy are finally balanced on the border between fiction and non-fiction. He devoted two novels to an investigation of the figure of his father, before turning in Not Art ${ }^{\text {lix }}$ to his mother, whose worldview is determined by football. The leitmotiv of the novel is given by this character for whom the whole world is summarized by the rectangle of the football pitch, for whom the world is made of such rectangles. The football pitch embodies the universal principle. In a characteristically ironical passage, the author recounts his mother's dismissal of his book about football, Utazás a tizenhatos mélyére (Voyage to the end of the Penalty Area, 2006), thus blurring further the border between fiction and non-fiction: the (supposedly) non-fictional book by Esterházy is discussed in his (supposedly) fictional book ${ }^{1 \mathrm{x}}$. In both books, the figure of the Hungarian legend, Ferenc Puskás, stands out of the narrative. In Not Art, the friendship between the mother and Puskás is based on the same relationship to football, on the necessity to ignore the world beyond the football pitch.

The occasion for Voyage to the end of the Penalty Area was a commission by the newspaper Süddeutsche Zeitung to write a book about football on the occasion of the 2006 World Cup in Germany. The resulting narrative, balanced on the border between fiction and non-fiction, brings together his own recollection as a football player, the sense of ageing involved in playing the game, the nature of the sport in the lower divisions, the success of his brother, the nature of German football and of Germany, as well as, of course, obsessive memories of the famous 1954 world cup final in which Germany defeated the Hungary of Puskás et al. 3-2 $2^{1 \times i}$ with an equalising goal by Puskás having been disallowed for off-side. This event is an open wound, perhaps in the national psyche, certainly in the author's consciousness, who cannot bear to talk about it, and cannot bear either to be silent about it: "with all my strength, I tried to eradicate these ninety minutes from the History of the world."xii He later tries to find (ir)rational explanations for this defeat. ${ }^{\text {lxii }}$ He then opts for straight denial, disclosing the truth to the German people: in Bern, the Hungarians had won 3-2. And finally acknowledges the fact that the Hungarians had not won 3-2, but that the match was actually a draw... 
Having played in the fourth division, the author explains that watching football can be done as a supporter, but that he always watches it from the inside, as a player. He also considers the game as a writer, as a man of letters, noting for instance that Hidegkuti, who was also part of the magical generation of Hungarian football, was able, simply by taking an unforeseen step back, to create a new space. But the position he adopts, and states, is made clear from the beginning: "I was a footballer before I became a writer." "lxiv Although he brings a writer's point of view to the game, he turns the tables round and reflects on literature from the point of view of sport. He transforms for instance Sándor Márai's injunction to read with force into a commandment on watching matches with force: matches must be watched, says Esterházy, with passion, unswerving concentration, silence, elegance, generosity. Even drinking beer in the pub after the game is a form of art, which involves experience, talent, regularity, perseverance and style. Conversely, Puskás becomes the grand narrative, "the last flash of the total personality and of a destiny ready to happen, who could still say (with his game) 'I', like Theodor Fontane." ${ }^{\mathrm{x} v}$ He indulges in what he calls a "close reading" of Puskás, to assert that the footballer was the last total personality, the last to unite harmoniously heart, spirit, and reason. And because he could not stop halfway, he also sees in Puskás a figure consonant with contemporary art, "the first of the postmoderns, Puskás, who does not even exist, there are only ideas about him, he is a blank page on which anyone can write what they want, the hero of a fairy-tale who defeats everything for us...",xvi

Because the tone is often ironical, Esterházy tells the reader that he will pretend that one can learn everything about a country through its football and commonplaces, which, he says, are not inventions but the lies of reality. This enables him to turn to German, Hungarian, Italian football, and to view the sport as part of the culture. It is of course Hungarian football that he comes back to, in order to celebrate its golden age, to lament its downfall. In a series of short parallels, he compares Hungarian football to other national traditions (suggesting for instance that the Italian boast a quasi-genetic talent), to other passions. To be in love, he reminds us, is a great privilege, but to be in love with Hungarian football, these days, is so ridiculous, so devoid of class and panache, that its very existence, he claims, ought to be questioned. The disjointed construction, the collage effect of the narrative, the ironical tone transform our perceptions of football, enabling us to move in history, to experience 
the glory and the disappearance of the Hungarian football team. But Esterházy also takes the reader through society, to partake of local football and national traditions, to negotiate the collective feeling that the game generates and the individual sense of what it is to be a footballer, even an ageing one, to understand that when we think and read and talk about football, we need the language of an Esterházy, a man who is both a footballer and a writer.

Football is about heroes and their celebration. It is about fans and the support and loyalty they bring to the game. It is about the nation and the sense of identification that the sport brings to the spectators. But when it is read through the prism of literature, our understanding of the sport may be transformed. When football is not merely a metaphor but forms the core of the narrative, it enables the reader to perceive and reflect upon the place of the game at the heart of a culture. Football constitutes an enabling trope to explore the tensions, the frailties and the perplexities of our society. This is often done through the acute definition of voices, from David Peace's ventriloquising of Clough to the drifting characters of Mauvignier's novel around the Heysel, from Esterházy's idiosyncratic position as a writer who was first a footballer to Eoin, who stands for all Irish supporters and all Irish emigrants. None of these texts are really about football, but about fans, spectators, audience. They invite us to adopt a similar viewpoint, they insist on the position of the reader, on the edge, as it were, of the game. They suggest a parallel between the act of reading and the position of the spectator. In this sense, to read literature about sport, to read sport as if it was literature, to think about the connections between both, is perhaps a way of understanding sport that journalistic accounts will never afford. It is a way of feeling at home in the world of sport, knowing that literature defines us, through reading.

\footnotetext{
${ }^{\mathrm{i}}$ Pinter, The Dumb Waiter, 94-5.

ii "I tend to think that cricket is the greatest thing that God created on earth," Harold Pinter once said, "certainly greater than sex, although sex isn't too bad either", The Guardian, 27 December 2008.

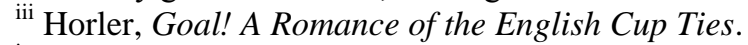

iv Hughes, Tom Brown's School Days. On the subject of boys' literature about sport, see Boyd, Manliness and the Boys' Story Paper in Britain.

${ }^{v}$ In France, for instance, the Michel Vaillant comics initiated generations of young readers into the complex workings of Formula One racing - and are said to have fostered the vocation of French Formula One driver Alain Prost.

${ }^{\mathrm{vi}}$ In the aftermath of every world cup since, there have been a number of fans' accounts of their travels with the England team, such as Moran, We are Nippon. Winner, Around the world in 90 presents an interesting variation on the subject, since it is a travelogue which reports on the writer's travels around
} 
the world at the time of the 2006 World Cup. For an overview of such literature, see Dart, "'Here We Go, Here We Go'."

vii Woodridge, "These Sporting Lives."

viii Greaves, This One's on Me; George Best Where Do I Go from Here?

${ }^{\text {ix }}$ Hamilton, Gazza Agonistes.

${ }^{\mathrm{x}}$ Winner, Those Feet.

${ }^{\mathrm{xi}} \mathrm{Cf}$. "Fever Pitch is about being a fan. I have read books written by people who obviously love football, but that's a different thing entirely" Hornby, Fever Pitch, 11-12.

${ }^{x i i}$ King, The Football Factory; Headhunters; England Away. Brimson, Hooligan. Anderson, Casual. On the complexities of the reception of the works of John King as well as on the reception of the film that was made of The Football Factory, see Redhead, "This Sporting Life."

xiii See in this issue, Papakonstantinou, "The Athletic Body in Classical Athens."

${ }^{\text {xiv }}$ Looking for Eric, directed by Ken Loach (2009).

${ }^{\mathrm{xv}}$ There are a number of variations on the genre of the documentary about famous footballers, some of the more innovative being for instance Zidane: a Portrait of the $21^{\text {st }}$ Century which records all the movements of Zinedine Zidane during a single football match, without ever showing the game. The result is a piece which avoids many of the pitfalls of cinema about football by refusing the drama of a match and by forcing the spectator to focus on an individual player, rather than on the team. In the same vein, one may mention Maradona by Kusturica (directed by Emir Kusturica, 2008) a film which, unlike the other two films mentioned above, is a genuine biographical documentary about the Argentinian player.

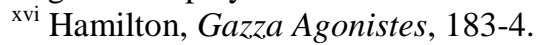

${ }^{\text {xvii }}$ The Olympian is for instance about a runner.

xviii Of particular interest here is Goalkeepers are Different (1971) which concentrates on the fascination exerted by goalkeepers.

${ }^{\text {xix }}$ One would want to pause and think here of all the great heroes of sport whose downfall was also brought about by the nature of the sport itself, be it the abuse of performance-enhancing drugs as in the case of a number of cyclists, Marco Pantani or Laurent Fignon, the contrast between permanent glory and solitary retirement as in the case of Björn Borg and others, or indeed the simple self-destructive mode that was enhanced by the glory of sport.

${ }^{\mathrm{xx}}$ Glanville, The Dying of the Light, 80.

${ }^{x x i}$ Glanville, The Dying of the Light, 95.

${ }^{x x i i}$ Peace, The Damned United. The Damned United, directed by Tom Hooper (2009).

xxiii Echenoz, Running.

${ }^{\mathrm{xxiv}}$ Peace, The Damned, 6.

${ }^{\mathrm{xxv}}$ Peace, The Damned, 84.

xxvi Peace, The Damned, 347.

${ }^{\text {xxvii }}$ Hamilton, Gazza Agonistes, 5.

xxviii On cricket and literature see Tadié, "The Fictions of (English) Cricket". This is of course a generalisation - there is a tradition in football literature which connects directly with the public school novel, in the wake of Tom Brown, and which concentrates on the game on the pitch — Barry Hines's $A$ Kestrel for a Knave (1968) offers long descriptions of football matches at the school, which were used to great effects in Ken Loach's film of the novel, Kes (1969).

${ }^{x x i x}$ Hooliganism was indeed the central problem of English football in the 1970s and 1980s with violent fights taking place at many stadiums. It was organised around gangs of supporters and was only controlled at the end of the 1990s.

${ }^{\mathrm{xxx}}$ King, England Away, 104.

${ }^{x x x i}$ King, The Football Factory, 31.

xxxii King, The Football Factory, 63.

xxxiii Priestley, The Good Companions, 5-6.

${ }^{x x x i v}$ King, The Football Factory, 155.

${ }^{\mathrm{xxxv}}$ King, The Football Factory, 208.

${ }^{x x x v i}$ King, The Football Factory, 6.

xxxvii King, The Football Factory, 52.

xxxviii King, The Football Factory, 125.

xxxix King, The Football Factory, 61. Or again: "Derby may be fuck all when it comes to football, but they've got a few faces prepared to do the business." (King, The Football Factory, 252).

${ }^{\mathrm{xl}}$ Cf. Skinheads.

${ }^{x l i}$ King, The Football Factory, 210. 
${ }^{x}$ lii King, The Football Factory, 13. The parallel between sport and war, and in particular between football encounters with Germany and the two World Wars is ubiquitous, including in supporters' songs: "Two World Wars, one World Cup", as if, in a football context, English supporters could only view Germany through the superimposition of football (the 1966 World Cup) and war.

xliii Other films have portrayed this subculture of football, such as Alexander's Green Street (2005) or This is England, the 2006 film directed by Meadows. But the reality of skinhead influence on the culture of football must be qualified. There are a number of studies of this phenomenon, such as Back, Crabbe and Solomos, "Beyond the Racist/Hooligan Couplet." See also Hughson and Poulton, "This is England." In particular p. 517: “...our concern is that by riding on the back of a well-established moral panic, initiatives such as England fans keep alive the 'folk-devil' of the extremely outdated skinhead football hooligan stereotype. In turn, such promotion abets a counter-ethnocentric marginalization whereby the 'rough', male, white working class is perceptually labelled as deviant symbolically guilty until proven otherwise." On fan culture in general, in a comparative perspective, see Finn and Giulanotti, eds., Football Culture.

${ }^{\text {xliv }}$ Mauvignier, In The Crowd.

${ }^{x l v}$ King, England Away, 60.

${ }^{x l v i}$ King, England Away, 251.

xlvii "What has made sport so uniquely effective a medium for inculcating national feelings, at all events for males, is the ease with which even the least political or public individuals can identify with the nation as symbolized by young persons excelling at what practically every man wants, or at one time in life has wanted, to be good at. The imagined community of millions seems more real as a team of eleven named people. The individual, even the one who cheers, becomes a symbol of his nation himself." Hobsbawm, Nations and Nationalism, 143.

xlviii This of course refers to the Republic of Ireland. On football and Ireland, see also Doyle, "Republic is a Beautiful Word". On the relationship between football and nationalism in Northern Ireland, see for instance Hassan, "A People Apart”.

xlix Bolger, In High Germany, 37.

${ }^{1}$ Bolger, In High Germany, 42-3.

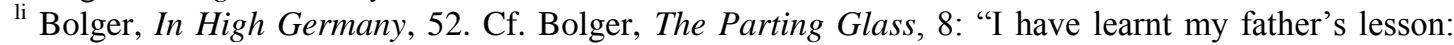
you should never return, but I can't fully let go of Ireland though. In dreams I'm still here and every time they play soccer I find a television. Those eleven men in green - twinning the accents from the sons of those who stayed and those forced to leave - feel like the only Ireland I still belong to."

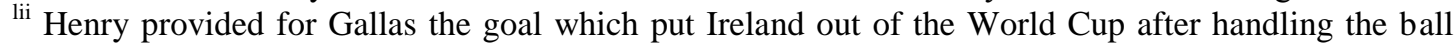
twice in six-yard box. A Google search on the words 'Ireland France Thierry Henry' yielded 2810000 results on 16 April $2012 \ldots$

liii "Da: the absence in my life, the man forced to leave his family to seek work in an English car plant. All my uncles have left and taken their children with them, but Da is stubborn. Da wants me to grow up with an Irish accent under an Irish flag" (Bolger, The Parting Glass, 3).

${ }^{\text {liv }}$ Bolger, The Parting Glass, 15.

lv "Theo wants me to invest my statutory redundancy in more Anglo Irish shares. Their price keeps plummeting, based on false rumours, he says. I should snap them up with balls of steel while money I invested for Dieter's future disappears as Irish shares keep tumbling. Do I ride the market or cut my losses. I don't know what to do. I'm filling in job application forms and not even getting replies. I'm checking the stock market every half hour, trying to stop calculating how much we've lost. I'm not sleeping: the walls of the apartment growing in on me. I'm in a limbo of CVs and the sort of queues I left Ireland to avoid twenty-five years ago" (Bolger, The Parting Glass, 29).

lvi Bolger, The Parting Glass, 35

lvii Bolger, "Author's Note."

lviii Bolger, The Parting Glass, 31.

lix Esterházy, Not Art. The novel is centered on the figure of the mother, with whom the narrator discusses time and again the off-side rule, but the defining moment in the book is the visit to the great hero of Hungarian football, Puskás.

${ }^{\mathrm{lx}}$ The book is as yet not translated into English. I have used and quoted from the French translation, Voyage au bout des seize mètres. The translations from French into English are mine.

lxi The event is celebrated from a - needless to say — different perspective in the immensely popular Das Wunder von Bern [The Miracle of Bern] (2006), a film by Sönke Wortmann.

lxii Esterházy, Voyage, 136.

${ }^{\text {lxiii }} \mathrm{He}$ alludes indirectly to the famous controversy about the fact that the Germans players might have been doped. 


\footnotetext{
${ }^{\text {lxiv }}$ Esterházy, Voyage, 36.

${ }^{\mathrm{lxv}}$ Esterházy, Voyage, 149.

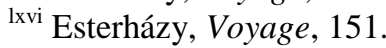

References

Alexander, Lexi. Green Street (2005)

Anderson, Gavin. Casual (Dunoon: Low Life, 1996).

Back, Les, Tim Crabbe and John Solomos. "Beyond the Racist/Hooligan Couplet: Race, Social Theory and Football Culture", The British Journal of Sociology 50, 3 (1999): 419-442.

Best, George. Where Do I Go from Here? (London: Queen Anne Press, 1981). Hamilton, Ian. Gazza Agonistes (London: Bloomsbury, 1998).

Bolger, Dermot. "Author's Note," The Parting Glass, 2010, http://www.dermotbolger.com/plays_thepartingglass.htm (last accessed 16 April 2012).

Bolger, Dermot. In High Germany (Dublin: New Island, 1999).

Bolger, Dermot. The Parting Glass (Dublin: New Island, 2011).

Boyd, Kelly. Manliness and the Boys' Story Paper in Britain: A Cultural History, 1855-1940 (London: Palgrave Macmillan, 2003).

Brimson, Eddy. Hooligan (Edinburgh: Mainstream, 1998).

Dart, Jonathan. "Here We Go, Here We Go'. Football Fans' World Cup Travelogues", Sport in History, 29, 2 (2009): 311-329.

Doyle, Roddy. "Republic is a Beautiful Word" in Nick Hornby, ed., My Favourite Year: A Collection of New Football Writing (London: Witherby, 2001): 9-28.

Echenoz, Jean. Running, translated from the French by Linda Coverdale (New York: The New Press, 2009).

Esterházy, Péter. Not Art: A Novel, translated from the Hungarian by Judith Sollosy (New York: HarperCollins, 2010).

Esterházy, Péter. Voyage au bout des seize mètres, translated from the Hungarian by Agnès Járfás (Paris: Christian Bourgois, 2006).

Finn, Gerry and Richard Giulanotti, eds., Football Culture: Local Contests, Global Visions (London: Frank Cass, 2000).

Glanville, Brian. Goalkeepers are Different (London: Hamish Hamilton, 1971).

Glanville, Brian. The Dying of the Light (London: Faber and Faber, 1976).

Glanville, Brian. The Olympian (London: Secker and Warburg, 1969).

Gordon, Douglas and Philippe Parreno, Zidane: a Portrait of the $21^{\text {st }}$ Century (2006).

Greaves, Jimmy. This One's on Me (London: A. Barker, 1979).

Hassan, David. "A People Apart: Soccer, Identity and Irish Nationalists in Northern Ireland", Soccer and Society, 3, 3 (2002): 65-83.

Hobsbawm, Eric. Nations and Nationalism Since 1780: Programme, Myth, Reality (Cambridge: Cambridge University Press, 1990).

Hooper, Tom. The Damned United (2009).

Horler, Sydney. Goal! A Romance of the English Cup Ties (London: Odhams, 1920).

Hornby, Nick. Fever Pitch (London: Victor Gollanz, 1992)

Hughes, Thomas. Tom Brown's School Days (London: Macmillan, 1857).

Hughson, John and Emma Poulton. "This is England': Sanitized Fandom and the National Soccer Team", Soccer \& Society 9, 4 (2008): 509-19.

King, John. The Football Factory (London: Jonathan Cape, 1996).

King, John. Headhunters (London: Jonathan Cape, 1997).

King, John. England Away (London: Jonathan Cape, 1998).

King, John. Skinheads (London: Jonathan Cape, 2008).

Kusturica, Emir. Maradona by Kusturica (2008).

Loach, Ken. Looking for Eric (2009).

Mauvignier, Laurent. In The Crowd, translated from the French by Shaun Whiteside (London: Faber and Faber, 2008).

Meadows, Shane.This is England (2006).

Moran, Simon. We are Nippon. The World Cup in Japan (Hyogo : S.U. Press, 2002).

Peace, David. The Damned United (London: Faber and Faber, 2006). 
Pinter, Harold. The Dumb Waiter, in The Caretaker and The Dumbwaiter: Two Plays (New York, Grove Press, 1960, 1988).

Priestley, J.B. The Good Companions (London: Heinemann, 1929).

Redhead, Steve. "This Sporting Life: The Realism of The Football Factory", Soccer and Society 8, 1 (2007): 90-108.

Tadié, Alexis. "The Fictions of (English) Cricket: From Nation to Diaspora", International Journal fo the History of Sport, 27, 4 (2010): 690-711.

Winner, David. Around the world in 90 minutes (+ extra time and penalties) (London : Bloomsbury, 2007).

Winner, David. Those Feet: A Sensual History of English Football (London: Bloomsbury, 2005).

Woodridge, Joyce. "These Sporting Lives: Football Autobiographies 1945-1980", Sport in History 28, 4 (2008): 620-640.

Wortmann, Sönke. Das Wunder von Bern (2006). 